\title{
AUTONOMIA E HETERONOMIA NA MORAL ${ }^{1}$
}

\author{
Gilmar Francisco Bonamigo \\ DFIL/UFES
}

Resumo: Este texto trata da questão do Fundamento da Moral em Immanuel Kant e Emmanuel Lévinas. Percorrendo o caminho kantiano que vai da Crítica da Razão Pura à Crítica da Razão Prática, encontraremos a Autonomia da Liberdade como o ponto decisivo para a compreensão da moralidade no homem; penetrando em Totalidade e Infinito e em De Outro Modo que Ser, desvelaremos com Lévinas a Heteronomia da Alteridade como o elemento que faz da Ética uma Filosofia Primeira. 0 texto aponta também algumas aproximações possíveis entre Kant e Lévinas, a partir do movimento interno de fundamentação de cada um.

Palavras-chave: Kant, Lévinas, ética, autonomia, heteronomia.

Abstract: This paper deals with the issue of Moral foundation in Immanuel Kant and Emmanuel Levinas. Following the Kantian path that extends from the Critic of Pure Reason to the Critic of Practical Reason, we will argue that the Autonomy of Liberty is the decisive point for the understanding of human morality; with Levinas' Totality and Infinity and Otherwise than Being,on the contrary, we will reveal the heteronomy of Alterity as the element that makes Ethics a Primary Philosophy. The article also seeks to explore some possible connections between Kant and Levinas by looking at the internal grounding movement of both philosophers.

Key words: Kant, Levinas, ethics, autonomy, heteronomy.

\footnotetext{
${ }^{1}$ Este texto foi produzido para a IX Semana de Filosofia, promovida pelo Departamento e pelo Curso de Filosofia da Universidade Federal do Espírito Santo, realizada em abril de 2005.
} 


\section{Introdução}

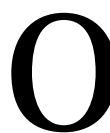

texto que aqui apresentamos é uma tentativa de aproximação, pela via da 'questão Moral', entre dois grandes pensadores da História da Filosofia: Immanuel Kant e Emmanuel Lévinas. São dois grandes pensadores em vários sentidos, dentre os quais destacamos: a amplitude da obra, a radicalidade da argumentação, os problemas aos quais consagraram a maior parte de seu esforço filosófico. Dentre a multidão de problemas abordados por Kant e Lévinas, vemos, com efeito, que há um esforço imenso em ambos por recolocar no horizonte da filosofia a discussão sobre a questão da Ação humana, tantas vezes protelada em favor da questão do Conhecimento, sobretudo da Modernidade aos nossos dias. Kant é 'moderno' no sentido forte do termo e é lugar de passagem obrigatória para a tematização de muitos problemas; Lévinas é 'contemporâneo' e viveu sob as conseqüências e sob a crise do 'projeto' moderno - no qual se insere a filosofia kantiana - em que a Subjetividade humana foi erigida ao nível de ponto arquimediano de toda a constituição do Sentido, o que fez Lévinas buscar uma espécie de 'novo ponto de partida' para o filosofar.

A nossa atenção aqui será centrada na questão do fundamento da Moral. Dada a imensidão da obra de Kant e de Lévinas, bem como a centralidade da moral em ambos, às vezes precisaremos fazer alguns desvios para preparar a compreensão do ponto em questão; nesses desvios muitos problemas serão citados ou abordados apenas até o ponto em que contribuem para a explanação do problema central. Também precisaremos recorrer a abundantes citações para manter a fidelidade ao pensamento dos Autores e 0 diálogo entre eles.

Quanto a Kant, a obra principal que nos serve de guia na busca do fundamento da moral é a sua Crítica da Razão Prática; quanto a Lévinas, ficaremos mais restritos a duas obras principais, quais sejam, Totalidade e Infinito e De Outro Modo que Ser ou o mais Além da Essência. Como veremos no desdobrar do texto, para Kant a Autonomia da Liberdade é o fundamento da moral: sem tal autonomia seria impensável a moralidade do homem e a moralidade entre os homens; em Lévinas é a Heteronomia da Alteridade, entendida como o 'outro humano' e o 'Outro Infinito', que impõe a cada homem uma investidura à sua liberdade e a põe na rota da responsabilidade pelo outro. Por fim, acompanhando o movimento de fundamentação de cada um, veremos que, apesar da especificidade de cada pensador e das divergências profundas, em muitos pontos Kant e Lévinas se aproximam e mesmo se tocam. 


\section{Kant e o Fundamento da Moral}

É um lugar-comum no horizonte filosófico considerar Immanuel Kant um 'divisor de águas' na História da Filosofia. Uma seria a situação da filosofia antes, outra a situação ulterior. Na verdade, a obra kantiana, por um lado, condensa e exprime uma síntese original na qual toda a tradição filosófica é retomada e, por outro, as respostas kantianas irão determinar em larga medida o modo e 0 tom do filosofar posterior. 0 estabelecimento dos limites do Conhecimento e a afirmação da impossibilidade da Metafísica como Ciência, por exemplo, fazem parte dessa incidência filosófica. $\mathrm{Na}$ filosofia contemporânea e mesmo na atualidade, são raros os problemas cuja tematização não exija um retorno ou pelo menos um confronto com Kant.

0 conjunto da obra kantiana pode ser resumido em três grandes questões². A primeira, o que posso conhecer? A segunda, como devo agir? A terceira, o que posso esperar? Haveria uma quarta pergunta, o que é o homem?, que ficou latente no pensamento kantiano. A resposta à primeira encontramos na densidade argumentativa da Crítica da Razão Pura; à segunda e terceira Kant responde principalmente na Crítica da Razão Prática; a resposta à quarta questão não foi explicitamente tematizada, embora possamos detectar alguns dos traços do homem kantiano ao longo de toda a sua obra. Outros problemas também são importantes, como a questão do Belo, que mereceu de Kant uma Crítica do Juízo, mas não possuem a incidência valorativa das outras duas Críticas.

A análise que nos propomos efetivar acerca do problema do fundamento da moral em Kant precisa passar por um caminho que se constitui numa espécie de desvio. Com efeito, o problema da moral, embora seja, ao nosso ver, o problema por excelência de toda a obra kantiana, é um problema cujo desenvolvimento e elucidação necessitam de um caminho prévio que passa, segundo o próprio itinerário kantiano, pelo enfrentamento de outros problemas, em especial o do Conhecimento. É assim que o próprio Kant escreve primeiramente uma Crítica da Razão Pura e depois uma Crítica da Razão Prática.

\section{A . O problema do Conhecimento}

$\mathrm{Na}$ abordagem kantiana do Conhecimento insere-se decisivamente a incidência da Ciência experimental, em especial a Física newtoniana. 0 que

\footnotetext{
${ }^{2}$ KANT, I., Crítica da Razão Pura. Tradução de Valério Rohden e Udo Baldur Moosburger. São Paulo: Nova Cultural, 1987, 3a ed., Vol. 2, 223.
} 
Kant percebe é que, desde as bases postas para a ciência na aurora da modernidade por Copérnico e Galileu e depois com a 'maturação' do método operada por Newton, o conhecimento científico alcançou um tal progresso e riqueza de resultados que se tornou um fato inegável. A Ciência moderna torna-se para Kant uma espécie de ponto de partida para a abordagem epistemológica, mesmo que as preocupações e interesses kantianos maiores sejam pela Metafísica. É na Crítica da Razão Pura que ele procura desdobrar e explicitar a questão do que posso conhecer?

Se a Ciência consegue um progresso inimaginável, a primeira pergunta que se impõe a Kant é a respeito do como ou pelo modo de funcionamento da Ciência. Abrindo, por assim dizer, o véu e penetrando na constituição da Ciência, Kant verá que ela é constituída fundamentalmente de juízos. Um juízo é uma proposição onde se dá a conexão de dois conceitos, dos quais um cumpre a função de sujeito(A) e o outro de predicado(B).

Logo se põe a seguinte pergunta: quais os tipos ou qual o tipo de juízo específico da Ciência? Abrindo de novo o véu, Kant perceberá que a Ciência é constituída por três tipos de juízos: Analíticos, Sintéticos a posteriori e Sintéticos a priori. Os analíticos teriam como características o de serem universais e necessários, mas não ampliadores do conhecimento, porquanto o predicado já está contido no sujeito da proposição; basta analisar o sujeito para extrair dele o predicado; tais juízos servem principalmente para organizar os conhecimentos científicos. Os dois tipos de juízos sintéticos, por sua vez, segundo o olhar kantiano, sempre ampliam o conhecimento, pois dizem sempre algo de novo acerca do sujeito. Porém, os sintéticos a posteriori, como juízos experimentais e mais comuns, não possuem as características de universalidade e necessidade; embora presentes na Ciência, não são os decisivos. Já os sintéticos a priori, seriam aqueles que reúnem a universalidade, a necessidade e a fecundidade em suas proposições. A conclusão kantiana é direta: os juízos específicos da ciência são os sintéticos a priori.

A próxima pergunta é sobre o fundamento dos juízos. Os analíticos teriam como fundamento o princípio de identidade e de não-contradição; dos sintéticos a posteriori seria a experiência; e dos sintéticos a priori? Aqui está o ponto decisivo, pois aqui se põe a 'grande luz' que Kant diz ter recebido em 1769 e aquilo que ele chamou de a sua 'revolução copernicana'. 0 fundamento dos juízos sintéticos a priori, que são os específicos da Ciência, é o próprio Sujeito que pensa e sente, o Sujeito com as leis de sua Sensibilidade e de seu Entendimento. Daí se compreende a célebre frase kantiana: “... a razão só discerne o que ela mesma produz segundo o seu projeto, ela tem que ir à frente com princípios dos seus juízos segundo leis constantes e obrigar a natureza a responder às suas perguntas" ${ }^{\prime 3}$. E com

3 Ibid., v. 1, 13. 
isso, conforme a 'revolução copernicana' de Kant, não é o sujeito que deve girar ao redor do objeto, mas o objeto que deve girar ao redor do sujeito.

O passo seguinte dado por Kant na Crítica da Razão Pura é o de 'abrir' 0 Sujeito para ver nele o que torna possível os juízos sintéticos a priori, explicitar as estruturas cognoscitivas do sujeito e o seu modo de funcionamento. A Estética Transcendental tratará da primeira estrutura a priori que Kant denomina de Sensibilidade. Abrindo a Sensibilidade, Kant descortina as duas formas pelas quais a Sensibilidade opera: o Espaço e o Tempo, que são formas a priori da intuição sensível. A Sensibilidade é "a capacidade (do Sujeito) de obter representações mediante o modo como somos afetados por objetos"4. Daí, afirma Kant que "toda nossa intuição não é senão a representação de fenômeno: que as coisas intuímos não em si mesmas tal qual as intuímos, nem que suas relações são em si mesmas constituídas do modo como nos aparecem e que, se suprimíssemos o nosso sujeito ou também apenas a constituição subjetiva dos sentidos em geral, em tal caso desapareceriam toda a constituição, todas as relações dos objetos no espaço e tempo, e mesmo espaço e tempo. Todas essas coisas enquanto fenômenos não podem existir em si mesmas, mas somente em nós. 0 que há com os objetos em si e separados de toda esta receptividade da nossa sensibilidade, permanece-nos inteiramente desconhecido. Não conhecemos senão 0 nosso modo de percebê-los, o que nos é peculiar e não tem que concernir necessariamente a todo ente, mas sim a todo homem" ${ }^{5}$.

Essa afirmação de Kant contém uma série de elementos importantes. Com efeito, e em primeiro lugar, a Sensibilidade é que intui; em seguida, ela intui por formas constitutivas dela que são o espaço e o tempo; estes, por sua vez, são como que as portas de entrada dos fenômenos na sensibilidade e como tais não provêm dos fenômenos e nem se confundem com eles, antes, permitem ao sujeito toda representação sensível. Os fenômenos são as manifestações das coisas para nós e não as coisas em si mesmas, mas a condição de receber as manifestações pertence universalmente ao sujeito em sua sensibilidade por suas formas a priori, o espaço e o tempo. Com isso, não precisamos sair de nós mesmos para conhecer o espaço e o tempo; eles já estão em nós e de forma pura, a priori; nós só podemos captar as coisas como espacial e temporalmente determinadas porque temos uma sensibilidade assim configurada.

\footnotetext{
4 I bid. v. 1, 39.

5 Ibid. 49.

6 Ibid. 55.
} 
Continuando a 'abertura' do Sujeito cognoscente em suas estruturas constitutivas, Kant descobre o Entendimento. Como diz Kant, "A nossa natureza é tal que a intuição não pode ser senão sensível, isto é, contém somente 0 modo como somos afetados por objetos. Contrariamente, a faculdade de pensar o objeto da intuição sensível é o entendimento" ${ }^{6}$. A Analítica Transcendental é que trata desta segunda estrutura a priori que torna possível o conhecimento. Abrindo o Entendimento e prescindindo de todo 0 conteúdo de conhecimento, Kant verá que o Entendimento é definível como a faculdade de Julgar, porque é ele que organiza o múltiplo sob uma representação comum; sua função não é intuir, mas julgar. Mas como é que - Entendimento julga? Perscrutando o Entendimento, Kant encontra as Categorias ou os Conceitos puros, uma série de doze Categorias'; é por elas que o Entendimento julga, unifica o múltiplo. Assim como espaço e tempo pertenciam a priori à constitutividade da Sensibilidade do sujeito, as categorias pertencem a priori à constitutividade do Entendimento do mesmo sujeito.

Dissemos que o Entendimento unifica o múltiplo pelas categorias. E de onde procede 0 múltiplo a ser unificado? "Sem sensibilidade nenhum objeto nos seria dado, e sem entendimento nenhum seria pensado. Pensamentos sem conteúdo são vazios, intuições sem conceitos são cegas. 0 conhecimento só pode surgir da sua reunião"8. Esta afirmação Kantiana é decisiva pois com ela está praticamente dada a resposta ao 'que posso conhecer?' - questão que orienta as buscas da Crítica da Razão Pura. 0 que posso conhecer são fenômenos (múltiplo) que são adentrados em minha Sensibilidade em suas (da sensibilidade) formas puras de espaço e tempo; sobre este conteúdo fenomênico é que o Entendimento aplica as suas categorias (julga), obtendo a cada aplicação uma síntese. 0 Entendimento e a Sensibilidade, com suas formas a priori são as condições de possibilidade dos juízos sintéticos a priori, específicos da Ciência.

Porém, temos ainda um problema: se a cada aplicação de uma categoria aqui e agora 0 entendimento produz uma síntese, ele não corre o risco de 'esquecer' as sínteses anteriores? É então que Kant introduz a figura do Eu Penso, também denominada de Apercepção Transcendental. Diz Kant: "0 eu penso tem que poder acompanhar todas as minhas representações... Portanto, todo o múltiplo da intuição possui uma referência necessária ao eu penso, no mesmo sujeito em que este múltiplo é encontrado. ... as múltiplas representações que são dadas numa certa intuição não seriam todas representações minhas se não pertencessem todas a uma autoconsciência" 9 .

\footnotetext{
${ }^{6}$ Ibid. 55.

${ }^{7}$ Cf. Crítica da Razão Pura, vol. 1, 70.

8 Ibid. 56.

9 Ibid. 81.
} 
Estabelecido o que é possível conhecer, Kant avança a reflexão sobre o fato de a Razão humana tender a ir além do âmbito fenomênico, que é o reino do cognoscível. É ali também que se põe a questão da possibilidade da Metafísica como Ciência. A Dialética Transcendental procura dar as razões dessa tendência e mostrar ao mesmo tempo as ilusões em que a razão cai quando tenta extrapolar, indo além da experiência possível. Com efeito, para Kant, quando a razão tenta ir além da experiência cai numa série de erros e ilusões que não são casuais, mas involuntários e necessários. Nós podemos nos defender das ilusões, mas não podemos afastá-las, visto que a tendência de 'ultrapassagem fenomênica' faz parte da própria natureza do homem enquanto homem; o espírito humano não pode deixar de ir além da experiência, na busca da coisa-em-si, porque isto constitui uma necessidade estrutural, a exigência do incondicionado ${ }^{10}$. A Razão seria a faculdade de silogizar, e faculdade dos princípios ${ }^{11}$, opera com conceitos e juízos puros, mas não pode pretender que seus juízos tenham valor de conhecimento.

Kant deduz da tábua de silogismos a tábua de conceitos puros da razão, que ele chamou de 'Idéias'. Elas seriam três: idéia de alma, idéia de mundo, idéia de Deus. A idéia seria então "um conceito a partir de noções, que ultrapassa a possibilidade da experiência"12. Mas se elas não podem pretender ser conhecimento verdadeiro, as idéias possuem uma positividade no uso 'normativo' que delas se pode fazer: elas valem como esquemas para ordenar a experiência e dar-lhe a maior unidade possível. Com outras palavras, as Idéias servem para organizar os fenômenos, 'como se' todos os fenômenos relativos ao homem dependessem de um princípio único (a alma), 'como se' todos os fenômenos da natureza dependessem de um princípio único (mundo), 'como se' a totalidade das coisas dependesse de uma inteligência suprema (Deus).

Com isto, já se encaminhando para o final da Crítica da Razão Pura, Kant conclui o processo afirmando, por um lado, e indagando, por outro: "Em seu uso especulativo, a razão conduziu-nos pelo campo da experiência e, por jamais poder encontrar uma satisfação cabal em tal âmbito, daí às idéias especulativas; ao fim e ao cabo, entretanto, estas últimas reconduziram-nos à experiência, realizando, portanto, o seu propósito de um modo proveitoso, se bem que de modo algum conforme às nossas expectativas. Agora resta-nos ainda uma alternativa: se também é possível encontrar a razão pura num uso prático, se de acordo com este último ela conduz às idéias que atingem os fins supremos da razão pura há pouco mencionados, e se sob o ponto de vista de seu interesse prático a razão não

\footnotetext{
10 Ibid. 15.

11 Ibid. vol. 2, 10.

12 Ibid. vol. 2, 18.
} 
nos pode conceder aquilo que nos declinou (negou) completamente com respeito ao interesse especulativo" ${ }^{13}$. Eis o fim da Metafísica como Ciência e como especulação. Este limite é também o que abre a passagem para Crítica da Razão Prática na busca de uma Razão Pura Prática, onde se põe o problema do Fundamento da moral.

\section{B. Liberdade, Autonomia, Moralidade}

0 desvio efetivado anteriormente nos mostrou a impossibilidade para a razão de avançar cognoscitivamente para além da experiência possível, ficando vetado o caminho metafísico pela via especulativa. Mas, abrindo de novo a Razão, já na Fundamentação da Metafísica dos Costumes Kant descortinava um novo uso da razão pura, não mais e apenas em seu uso teórico, mas sim seu uso prático, preservando, contudo, a unidade da razão. Com efeito, ele dizia: “... eu exijo, para que uma razão pura prática possa ser acabada, que se possa demonstrar simultaneamente a sua unidade com a razão especulativa num princípio comum; pois no fim de contas trata-se sempre de uma só e mesma razão, que só na aplicação se deve diferenciar"14. A razão não é só capaz de conhecimento; a razão é também capaz de ação, capaz de determinar a vontade e a ação moral.

A Crítica da Razão Prática, segundo Kant, "tem a obrigação de deter a presunção da razão empiricamente condicionada de querer, ela só e exclusivamente, fornecer o fundamento determinante da vontade. 0 uso da razão pura ... é unicamente imanente; o uso empiricamente condicionado, que se arroga ao domínio absoluto, é, ao contrário, transcendente e manifesta-se em pretensões e mandamentos que excedem totalmente seu domínio, que consiste precisamente na relação inversa do que podia ter sido dito sobre a razão pura no uso especulativo"15. Com outras palavras, 0 problema fundamental é o problema do fundamento da ação, mas da ação moral; a determinação da vontade como moralidade vai implicar em ultrapassar o empiricamente condicionado e contingente, avançando na direção do incondicionado, constituindo-se num movimento inverso ao da Crítica anterior. Por isso é que a Crítica é à Razão prática e não à Razão pura prática. E "se se admite que a razão pura possa conter um fundamento praticamente suficiente para a determinação da vontade, então existem leis práticas; do contrário, todas as proposições fundamentais práticas tornamse simples máximas" ${ }^{16}$. Aqui o caminho kantiano é este: abrindo a Razão

\footnotetext{
13 Ibid. vol. 2, 223.

${ }^{14}$ KANT, I., Fundamentação da Metafísica dos Costumes. Tradução de Paulo Quintela. São Paulo: Abril Cultural, 1974, 1a edição, 200.

${ }^{15}$ KANT, I., Crítica da Razão Prática. Tradução, introdução e notas de Valério Rohden baseada na ed. Original de 1788. São Paulo: Martins Fontes, 2002, 26.

16 Ibid. 33.
} 
Kant descobre o seu aspecto agente; abrindo a ação descobre a vontade sendo determinada por princípios práticos; procurando o movente determinador da vontade descobre o empiricamente condicionado (que é preciso ultrapassar) e a liberdade donde procedem as máximas com validade subjetiva e a lei moral com validade universal.

Vejamos primeiramente 0 que são proposições fundamentais práticas. Para Kant, "são proposições que contêm uma determinação universal da vontade, determinação que tem sob si diversas regras práticas" ${ }^{17}$. Se a condição for considerada pelo sujeito como válida somente para ele, então tais proposições são subjetivas ou máximas; se a condição for conhecida como objetiva, por ser válida para todo ente racional, então são leis. A partir daí, Kant distingue dois tipos de imperativos, como princípios práticos: hipotéticos e categóricos. Os primeiros conteriam simples preceitos de habilidade e seriam condicionados porque determinam a vontade tendo em vista um efeito apetecido e, como tal são preceitos, mas não leis (se quiseres vida longa, cuida da saúde); já os categóricos determinam a vontade enquanto vontade e por isso são constituídos pela necessidade e independência diante de condições contingentes, o que os faz válidos universalmente. A conclusão kantiana é a seguinte: "Todos os princípios práticos que pressupõem um objeto (matéria) da faculdade de apetição como fundamento determinante da vontade, são no seu conjunto empíricos e não podem fornecer nenhuma lei universal"18; com isso, todos os princípios práticos materiais "incluem-se no princípio geral do amor de si ou da felicidade própria" ${ }^{19}$, sendo com isso heteronômicos, visando algo fora do sujeito e sob as condições da contingência.

Mas, se um ente racional deve representar suas máximas como leis universais práticas, então ele somente pode fazê-lo como princípios que contêm o fundamento determinante da vontade não segundo a matéria, mas simplesmente segundo a forma. Os imperativos categóricos e somente eles são leis que valem incondicionalmente para o ser racional "porque a regra só é objetiva e universalmente válida se vale independentemente de condições subjetivas e contingentes... O simples querer é que deve ser determinado de modo completamente a priori por aquela regra" 20 . Assim, as leis práticas referem-se unicamente à vontade, tomada como pura, abstraída do mundo sensorial.

Se os imperativos categóricos, como leis práticas, são constituídos pela necessidade e universalidade à semelhança das leis naturais, isto não implica em identidade. Com efeito, enquanto as leis naturais não podem

\footnotetext{
17 Ibid. 31-32.

18 Ibid. 36.

19 Ibid. 37.

20 I bid. 35.
} 
deixar de se concretizar, as leis morais podem até não se concretizar (e é o que mais acontece), porque a vontade humana está sujeita não só à razão, mas também às inclinações, podendo se desviar. A necessidade da lei moral está em valer para todos os seres racionais sob a forma do dever de determinar a vontade sob o imperativo da validade universal da ação. Isto implica em pensar a vontade como totalmente independente da lei natural dos fenômenos; "uma tal independência, porém, chama-se liberdade no sentido mais estrito, isto é, transcendental"21, é uma vontade livre.

Com isso, liberdade e lei prática incondicionada referem-se reciprocamente. Mas, seguindo Kant, "eu pergunto onde começa o nosso conhecimento do incondicionalmente prático, se pela liberdade ou pela lei prática. Pela liberdade ele não pode começar; pois nem podemos tornar-nos imediatamente conscientes dela, porque seu primeiro conceito é negativo, nem podemos inferi-la da experiência, pois a experiência só nos dá a conhecer a lei dos fenômenos, por conseguinte o mecanismo da natureza, o exato oposto da liberdade. Logo, é a lei moral da qual nos tornamos imediatamente conscientes (tão logo projetamos para nós máximas da vontade) que se oferece primeiramente a nós e que, na medida em que a razão a apresenta como um fundamento determinante sem nenhuma condição sensível preponderante, antes, totalmente independente delas, conduz diretamente ao conceito de liberdade"22. E, ao projetar princípios de determinação da nossa vontade, como princípios subjetivos ou como imperativos categóricos, se prestarmos atenção à necessidade com que a razão prescreve proposições práticas puras, podemos tornar-nos conscientes da lei moral e, desta, da liberdade. Assim, "ela (a liberdade) é a condição da lei moral, que conhecemos" 23 .

Agora estamos em condições de compreender a fórmula kantiana - dita de várias maneiras - que expressa o imperativo categórico e faz a identidade entre subjetividade da máxima e objetividade da lei moral. Diz ele: "Age de tal modo que a máxima de tua vontade possa sempre valer ao mesmo tempo como princípio de uma legislação universal" ${ }^{24}$. Ou ainda, "Age como se a máxima da tua ação se devesse tornar, pela tua vontade, em lei universal da natureza"25. 0 que significa que a razão pura é por si só prática e dá a cada homem uma lei universal, que Kant chama de lei moral, a ser concretizada em cada ação. À consciência desta lei fundamental Kant dá o nome de factum da razão, porque não se pode inferi-la de dados antecedentes da razão e porque ela se impõe por si mesma a nós como uma proposição sintética a priori, que não é fundada sobre nenhuma

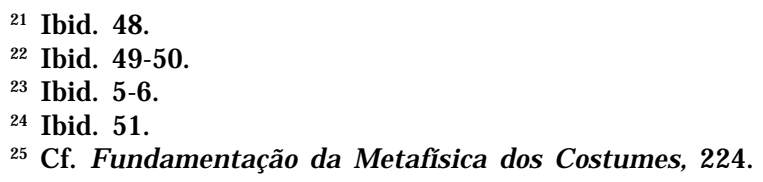


intuição, pura ou empírica; é por ela que a razão é originariamente legislativa.

As aproximações kantianas entre razão pura prática, lei moral e liberdade conduzem-nos agora diretamente ao problema da autonomia. Na verdade, este tema já esteve latente ao longo do caminho, mas só agora Kant 0 assume e o enfrenta. A tese kantiana aqui é a seguinte: "A autonomia da vontade é o único princípio de todas as leis morais e dos deveres conformes a elas: contrariamente, toda a heteronomia do arbítrio não só não funda obrigação alguma, mas, antes, contraria o princípio da mesma e da moralidade da vontade" ${ }^{26}$. A independência de toda a matéria da lei, de um objeto apetecido, é liberdade em sentido negativo e a legislação própria da razão pura é liberdade em sentido positivo. Com outras palavras, a lei moral é a expressão da autonomia da razão prática pura, isto é, da liberdade, e a liberdade é a condição formal de todas as máximas que devem estar em concordância com a lei prática suprema; sempre que houver heteronomia do arbítrio na forma de qualquer dependência de um impulso ou inclinação ocorre uma contrariedade à disposição moral, pois impede a exigência de universalidade para entes racionais. Mas "a lei dessa autonomia é a lei moral, que é, portanto, a lei fundamental de uma natureza supra-sensível e de um mundo inteligível puro, cujo equivalente deve existir no mundo sensível, mas sem ao mesmo tempo violar as leis do mesmo"27.

Encontramos aqui o grande duelo kantiano com a tradição filosófica. Com efeito, segundo Kant, os filósofos "procuravam um objeto da vontade para fazê-lo matéria e fundamento de uma lei... enquanto primeiro deveriam ter investigado uma lei que determinasse a priori e imediatamente a vontade e que, de acordo com ela, determinasse pela primeira vez o objeto. Ora, eles preferiam colocar este objeto do prazer, que deveria fornecer 0 conceito supremo de bom, na felicidade, na perfeição, no sentimento moral ou na vontade de Deus; assim a sua proposição fundamental consistia sempre em heteronomia e eles tinham que inevitavelmente encontrar condições empíricas para uma lei moral"28. A posição kantiana prescreve o contrário: "O conceito de bom e mau não tem que ser determinado antes da lei moral, mas somente depois dela e através dela" ${ }^{29}$.

Por isso entendemos que o motivo da disposição moral ter de ser livre de toda a condição sensível. É que, antes de tudo e em toda ação singular, "Dever e obrigação são as únicas denominações que temos de dar à nossa relação com a lei moral. Somos membros legislantes de um reino moral possível pela liberdade, representado pela razão prática para o nosso res-

\footnotetext{
${ }^{26}$ Cf. Crítica da Razão Prática, 55.

27 Ibid. 70.

28 Ibid. 102-103.

29 Ibid. 101.
} 
peito, mas ao mesmo tempo seus súditos, não o seu soberano" ${ }^{30}$. Isto significa que, para os homens e todo ente racional, a necessidade moral é uma necessitação, isto é, obrigação, e toda ação fundada sobre ela tem de ser representada como dever. Isto gera o primeiro sentimento moral que é o de respeito pela lei moral e de veneração pelo dever.

Mas Kant não é propriamente contra a felicidade; a questão é onde ela entra. Com efeito, "ser feliz é necessariamente a aspiração de todo ente racional, porém finito, um problema imposto a ele por sua própria natureza finita, porque ele é carente" ${ }^{31}$. Aquilo em que cada um põe a sua felicidade tem a ver com o sentimento particular de prazer e desprazer; trata-se de uma lei natural, subjetivamente necessária, mas é um princípio prático objetivamente contingente, pois varia muito entre os sujeitos diversos e, por isso, não pode fornecer uma lei. Então, se a felicidade é uma aspiração universal, mas profundamente variável em seu conteúdo, e se a lei moral tem como condição a autonomia, como vetor da universalidade e necessidade da lei moral, então o desejo de felicidade deve adequar-se ao princípio da lei moral, que obriga em si mesma e a partir de si mesma. Com outras palavras, "A razão prática pura não quer que se abandonem as reivindicações de felicidade, mas somente que, tão logo se trate do dever, ela não seja de modo algum tomada em consideração. Promover a sua felicidade jamais pode ser imediatamente um dever, menos ainda um princípio de todo o dever"32. Num primeiro tempo, trata-se de uma primeira resposta de Kant, pela via negativa, ao problema da articulação entre felicidade e moralidade.

Kant aprofunda esta resposta. Com efeito, para ele, todas as inclinações em conjunto (que certamente podem ser também compreendidas em um razoável sistema e cuja satisfação chama-se então felicidade própria) constituem o solipsismo. Este consiste ou no solipsismo do amor de si, como uma benevolência para consigo mesmo sobre todas as coisas, ou no solipsismo de complacência em si mesmo. Ao primeiro Kant chama de amor-próprio e ao segundo de presunção. A razão prática pura causa dano ao amorpróprio na exata medida em que ela o limita conforme a exigência incondicional da lei moral; o amor-próprio torna-se então amor de si racional. Com relação à presunção, a razão pura prática a abate porquanto as exigências de auto-estima não podem preceder a lei moral. E Kant sentencia: "a concordância com essa lei é a primeira condição de todo o valor da pessoa..." 33 .

\footnotetext{
30 Ibid. 133.

31 Ibid. 42.

32 Ibid. 151.

33 Ibid. 119.
} 
Nesse sentido, a lei moral exige o seu cumprimento mesmo que ele não venha a ocorrer de bom grado. Num ente sumamente perfeito a lei moral é uma lei de santidade; mas para a vontade de todo ente racional finito ela é uma lei do dever, da necessitação moral e da determinação de suas ações mediante 0 respeito por essa lei. Nos entes racionais finitos a situação é de 'disposição moral em luta, pois a vontade não se encontra em completa pureza das suas disposições. Essa disposição moral em luta é o que Kant chama de virtude ${ }^{34}$.

Vimos que a lei moral é afirmada como o único fundamento determinante da vontade pura. Acontece que se trata de um princípio formal que abstrai de toda a matéria ou de todo e qualquer objeto do querer. Eis que surge para Kant a necessidade de determinar o que seja o sumo bem, como 0 objeto total de uma razão prática pura. É na determinação do Sumo Bem que Kant fará uma articulação positiva entre exigência de moralidade e exigência de felicidade. Com efeito, Kant não duvida de que a virtude, como conformação continuada da vontade à lei moral e como merecimento a ser feliz seja a condição suprema, o bem supremo. $M$ as para ele a virtude ainda não é o bem completo e consumado, pois para sê-lo requer-se também a felicidade; seria absurdo para o homem ser carente de felicidade e, por sua virtude, digno de felicidade e, ao mesmo tempo não ser dela participante. Por isso, “... virtude e felicidade constituem em conjunto a posse do sumo bem de uma pessoa" ${ }^{35}$, mas com a advertência kantiana de que a felicidade seja distribuída em proporção à moralidade, que a virtude seja anterior e seja para a felicidade a sua condição.

Esta conexão entre virtude e felicidade no sumo bem é dita por Kant da seguinte maneira: "...portanto, 0 bem supremo enquanto primeira condição do sumo bem constitui a moralidade e, contrariamente, a felicidade em verdade constitui o segundo elemento do mesmo, contudo de modo tal que esta seja a conseqüência moralmente condicionada, embora necessária, da primeira. Unicamente nesta subordinação o sumo bem é o objeto total da razão prática pura, a qual necessariamente tem de representá-lo como possível, porque é um mandamento da mesma contribuir com todo o possível para a sua produção" ${ }^{36}$. Porém, para que essa conexão seja possível, Kant precisará pressupor uma unidade ao nível da coisa-em-si, entre a nossa causalidade natural (na qual se insere nossa exigência de felicidade) e a nossa causalidade livre (onde se inscreve nossa moralidade por auto-determinação da vontade pura pela lei moral). No fundo, tudo se encaminharia para a consecução do sumo bem. É o que veremos no terceiro postulado kantiano

\footnotetext{
34 Ibid. 137.

35 Ibid. 180.

36 Ibid. 193.
} 
A realização completa do sumo bem, por sua vez, também está penetrada de problemas e conduzirá Kant a afirmar os famosos postulados: da imortalidade, da liberdade, da existência de Deus. Com efeito, a realização do sumo bem é o objeto necessário de uma vontade determinável pela lei moral, o que implica numa conformidade plena das disposições à lei moral. Ora, tal conformidade tem que ser possível porque assim ordena o mandamento da própria lei moral. Mas tal conformidade seria a santidade, cuja perfeição nenhum ente racional do mundo sensorial é capaz em nenhum momento de sua existência. Isto implica em conceber a realização do sumo bem como um progresso ao infinito, o que leva a exigir que a existência e personalidade do ente racional seja perdurável também ao infinito. Este é o postulado da imortalidade da alma, como uma exigência da razão pura prática.

O postulado da Liberdade já foi em larga medida abordado quando do aparecimento do problema da consciência da lei moral. A liberdade é inferida, ou melhor, exigida pela lei moral como a capacidade humana de determinar-se autonomamente como causalidade livre. Ou como diz Kant, trata-se da "necessária pressuposição da independência (do homem) do mundo sensorial e da faculdade de determinação de sua vontade segundo a lei de um mundo inteligível, isto é, da liberdade" ${ }^{37}$. Ou como Kant já dizia na Fundamentação da Metafísica dos costumes, "temos que pressupôla se quisermos pensar um ser como racional e com consciência de sua causalidade a respeito das ações, isto é, dotado de vontade, e assim achamos que, exatamente pela mesma razão, temos que atribuir a todo ser dotado de razão e vontade esta propriedade de se determinar a agir sob a idéia de sua liberdade" 38 .

Quanto ao postulado da existência de Deus, Kant o põe como exigência no progresso de realização do sumo bem (que já pressupôs a imortalidade da alma), mas agora em termos da possibilidade de inclusão da felicidade no sumo bem, para o que é postulada uma causa distinta e anterior à causalidade moral e à causalidade natural. Com efeito, o homem vive no mundo, depende dele e este possui a sua causalidade, que é diferente da causalidade livre do homem, que não é o causador do mundo, como não o é do seu próprio desejo de felicidade. Para Kant, não é possível uma redução da causalidade natural à causalidade moral porque esta não é capaz de promover uma total adequação daquela a esta. Mas a conexão entre ambas é postulada como necessária, porquanto o sumo bem implica também a felicidade, e esta se põe do lado da causalidade natural. Então diz Kant: "Portanto é postulada também a existência de uma causa da natureza distinta da natureza em conjunto, e que contenha o fundamento dessa

\footnotetext{
37 Ibid. 213.

${ }^{38}$ Cf. Fundamentação da Metafísica dos Costumes, 245.
} 
interconexão, a saber, da exata concordância da felicidade com a moralidade. o sumo bem só é possível no mundo na medida em que for admitida uma causa suprema da natureza que contenha uma causalidade adequada à disposição moral" ${ }^{39}$. E Deus seria então o sumo bem originário, autor da natureza e causa da possibilidade do sumo bem derivado.

É importante notar que se as exigências da razão pura prática levaram ao postulado da existência de Deus, isto não quer dizer que, no final das contas, Deus se tenha tornado o fundamento último da moral. Com efeito, para Kant, embora seja moralmente necessário admitir a existência de Deus, a moralidade de cada homem, com a obrigação moral concernente, depende apenas da autonomia da própria razão. Nem o temor, nem a esperança podem se constituir em fundamento ou motivos para determinar uma ação como moral; a lei moral é dada a cada homem e vale em si mesma. E ela, a lei moral, conduz à religião, que seria o conhecimento de todos os deveres como mandamentos divinos enquanto leis essenciais de cada vontade livre por si mesma. Por isso Kant pode falar de uma fé racional pura, emergente das exigências postuladas por uma razão pura prática.

Podemos concluir este primeiro movimento de abordagem da Autonomia da liberdade como fundamento da moralidade, afirmando com Kant a proeminência da razão prática pura sobre a razão pura teórica. Com efeito, "Não se pode de modo algum exigir da razão prática pura estar subordinada à razão especulativa e, pois, inverter a ordem, porque todo interesse é por fim prático e mesmo o interesse da razão especulativa é somente condicionado e unicamente no uso prático é completo"40. A razão é uma, a razão é pura, e dois são seus usos fundamentais; mas o prático condiciona o teórico. Além do mais, todo ato humano implica em ter diante de si a Humanidade e, na ordem dos fins, o homem deve ser visto como fim em si mesmo, que jamais seja usado por alguém simplesmente como meio.

\section{Lévinas: Moralidade e Alteridade}

O Pensamento de Emmanuel Lévinas, sobretudo no que tange à questão moral, segue um caminho diametralmente oposto ao que tem sido a tematização filosófica moderna do problema. Com efeito, como vimos em Kant, a Liberdade é pensada como uma espécie de celebração filosófica, em cujo seio se inscreve a autonomia da vontade humana. Nesse sentido, livre seria o homem, ou melhor, o indivíduo que ouve a sua própria razão, que se dá a sua própria lei moral e a ela se submete. Ou ainda, como em

\footnotetext{
${ }^{39}$ Cf. Crítica da Razão Prática, 201-202.

40 Ibid. 197.
} 
Rousseau, livre é o povo que institui um contrato consigo mesmo, obedece às leis estabelecidas por uma vontade geral na qual cada cidadão reconhece a sua própria vontade. Dizendo com Lévinas, no pensamento europeu predomina uma tradição na qual "a espontaneidade da liberdade não se põe em questão. Limitá-la seria trágico e constituiria um escândalo" ${ }^{41}$. $\mathrm{Ou}$ ainda, "raciocina-se em nome da liberdade do eu como se ele tivesse assistido à criação do mundo e como se somente fosse possível tomar a cargo um mundo surgido de seu livre arbítrio. Presunções de filósofos, presunções de idealistas" 42 .

Como vemos, a posição de Lévinas não comunga com essa confiança na liberdade; ao contrário, ele a julga com severidade. Para ele, a liberdade não se põe em questão "a não ser na medida em que ela se encontra imposta a si mesma: se eu tivesse sido capaz de escolher livremente minha existência, tudo estaria justificado"43. Então, seria a consciência do fracasso, da violência possível a todo instante, caso as liberdades não tenham nenhum freio, aquilo que conduz os homens a limitar as ambições de sua liberdade e os leva a instituir leis para poderem viver em sociedade. A esta consciência do fracasso da liberdade Lévinas opõe a consciência de uma culpabilidade. 0 valor da liberdade não está em questão porque a liberdade fracassa, mas porque ela carece fundamentalmente de justiça e não pode garantir a moralidade. A moralidade não tem sua fonte na liberdade, mas na consciência de sua indignidade no face-a-face do outro que lhe causa vergonha e embaraço (honte) pelo exercício da uma liberdade assassina.

Com isto, o outro não estaria opondo sua liberdade à minha liberdade, ele não faria pesar sobre minha liberdade as ameaças de morte que obrigam a fazer contrato; o outro "põe em questão o direito ingênuo de meus poderes, minha gloriosa espontaneidade de vivente" ${ }^{44}$ e me abre para a consciência de que a moral começa quando a liberdade, ao invés de se justificar por ela mesma, se sente arbitrária e violenta. A importância deste ponto é decisiva: admitir esta idéia significa introduzir um princípio de heteronomia na fonte viva da moral; tal heteronomia é a presença do outro, da Alteridade.

\section{A . Autonomia X Heteronomia}

Ao reabilitar a noção de heteronomia Lévinas se separa de "toda uma tradição filosófica que procura em si o fundamento de si, longe das opini-

${ }^{41}$ LÉVINAS, Emmanuel, Totalité et Infinit: Essai sur l'Extériorité (TI). Paris: Kluwer Academic, Le Livre de Poche. Edition Original: Martinus Nijhoff, 1971, 81.

42 ID. De Otro modo que Ser, o mas allá de la esencia (AE). Salamanca: Ediciones Sígueme, 1999, tercera edición, 194.

${ }^{43}$ Cf. TI 81.

44 Ibid. 83. 
ões heterônomas"45, e ensina a remontar ao aquém da liberdade, na direção de uma alteridade que a investe, isto é, que lhe dá uma dignidade que a liberdade não pode se dar a si mesma, precisamente a dignidade moral. A moralidade não se funda sobre a vontade razoável e livre, isto é, sobre a autonomia soberana do eu, mas sobre a possibilidade de acolher o outro de tal maneira que ele tenha precedência (préséance) sobre mim. Como diz Lévinas, "a existência na realidade não está condenada à liberdade, mas investida como liberdade. A liberdade não é nuvem. Filosofar é remontar aquém da liberdade, descobrir a investidura que liberta a liberdade do arbitrário. 0 saber como crítica, como recuo aquém da liberdade só pode acontecer num ser que tem sua origem aquém de sua origem, que é criada"46. Nesse sentido heteronomia não equivale à escravidão; antes, é o seu contrário.

Nesse percurso de deslocamento do fundamento da moralidade na heteronomia, as M editações de Descartes, especialmente a terceira meditação, e o horizonte bíblico-judaico jogam um papel decisivo. Em Descartes Lévinas encontrará uma porta para a introdução de conteúdos bíblicos na filosofia e promover transformações inusitadas. Vejamos primeiro a importância de Descartes. Com efeito, na terceira meditação, depois de ter chegado à primeira certeza do Cogito, Descartes busca novas certezas para 0 mesmo. A primeira constatação é de que o Cogito contém em si a idéia de Deus como substância infinita de perfeições. A segunda constatação é a de que tal idéia não pode ser produzida pelo próprio Cogito porque ele se experimenta finito. Isto leva Descartes a afirmar a existência de Deus como Aquele que pôs no Cogito a idéia de perfeição infinita. Daí, para Lévinas, "a noção cartesiana da idéia do Infinito designa uma relação com um ser que conserva sua exterioridade total por relação àquele que 0 pensa" ${ }^{47}$.

Dessa meditação cartesiana o que mais interessa a Lévinas é a admiração e mesmo o espanto que a descoberta da desproporção entre o Cogito e a idéia de Deus opera sobre a subjetividade. Isto Descartes não tematizou. "Há no cogito cartesiano... uma parada arbitrária, que não se justifica por ela mesma" ${ }^{48}$, diz Lévinas. A ultrapassagem dessa parada mostra que a distância que separa realidade (ideatum) e idéia constitui o conteúdo da realidade mesma. Isto quer dizer que Deus consiste no mais além, consiste na exterioridade, como o Outro, naquilo que em si mesmo não cabe no Cogito. Por isto afirma Lévinas: "A distância entre eu e Deus, radical e necessária, se produz no ser mesmo"49. Ou ainda, "A distância que separa ideatum e idéia constitui aqui o conteúdo do ideatum mesmo. 0 infinito é

\footnotetext{
45 Ibid. 87.

46 Ibid. 83.

47 I bid. 42.

48 I bid. 93.

49 I bid. 40.
} 
o próprio de um ser transcendente enquanto transcendente, 0 infinito é 0 absolutamente outro" ${ }^{50}$. Com outras palavras, do transcendente nós só temos em nós a idéia, o transcendente não é a idéia, ele é exterior e distanciado porque ele é infinito. Apesar da proximidade da idéia de infinito, Deus permanece Estrangeiro a nós. "Mas, possuir a idéia do infinito é já ter acolhido Outro" 51 .

O horizonte no qual Lévinas vai buscar o conteúdo e a inspiração para inserir a moral e seu fundamento na heteronomia, na Exterioridade - de outro homem ou de Deus, Infinito, Alteridade - é a tradição hebraica como já indicamos - na qual se inserem também os comentários da tradição talmúdica na interpretação da Escritura judaica. Nessa tradição, a relação ética aparece como uma relação excepcional. Com efeito, o contato com um ser exterior, em vez de comprometer a soberania humana, a institui e a investe: 0 homem livre é aquele votado ao próximo52. A liberdade 'libertada' ou isentada de todo arbitrário é orientada por uma heteronomia infinitamente exigente; a obediência à lei de um Outro não significa servidão ou submissão a um tirano, mas sim a quebra da pretensão do Eu em ser o fundamento último e a revelação, a este Eu, das obrigações que introduzem o humano no ser. "Acolher o Outro é pôr minha liberdade em questão" 53 .

Isto implica um pressuposto que perpassa toda a obra de Lévinas, a saber, a noção de criação, em específico aqui, a condição do homem como criatura. Com efeito, em virtude da criação é que se produz a idéia de Infinito, que Descartes já encontrara no Cogito e que agora recebe nova claridade. A idéia de Infinito é por assim dizer a marca do Criador na criatura, permanecendo separado desta; por sua vez, na criatura, a idéia de Infinito, mais do que um pensamento, é Desejo do Outro, do totalmente Outro. A condição de criatura impede o homem de ambicionar um status de princípio de seus pensamentos, de suas palavras, de seus atos, numa palavra, ser o fundamento de si. A situação real do homem é a de ter de responder a uma Palavra que o precede e 0 apela. Neste sentido, "O milagre da criação consiste em criar um ser moral"54, ou ainda, "A maravilha da criação não consiste somente em ser criação ex nihilo, mas em levar a termo um ser capaz de receber uma revelação, de entender que ele é criado e para se pôr em questão"55. Daí, chama-se 'criatura' o homem enquanto a

\footnotetext{
50 Ibid. 41.

51 Ibid. 94.

52 LÉVINAS, E., Humanismo do Outro Homem (HH). Petrópolis: Vozes, 1993. Este tema é tratado sobretudo na Segunda parte, em especial em 'Humanismo e An-Arquia', a partir da página 81.

${ }^{53}$ Cf., TI, 84.

${ }^{54}$ Ibid. 88.

55 Ibid. 88 .
} 
unidade da liberdade espontânea abrindo caminho diante dela e capaz de crítica, ao ponto de pôr-se em causa num movimento em direção a sua própria precedência. E ela, a criatura, é investida, em sua própria criaturalidade, por uma vocação a responder à exterioridade de um apelo infinitamente atualizado na presença do Outro.

A noção de criação como milagre condiciona a recepção do apelo de Deus ao homem, apelo que a Bíblia transmitiu de início pelo vocativo 'onde tu estás?' dirigido a Adão. Somente um ser separado, porquanto criado, pode ser atento, capaz de escutar e de descobrir que o sentido do Eu(moi) está inteiramente na resposta que o homem dá a esta Palavra que o procura. Enquanto criatura, o homem descobre que o sentido de sua singularidade se revela não quando o Eu se esforça para se pôr firmemente no Ser, mas quando a sua atenção é requerida por uma exterioridade que o apela e mostra que o homem é capaz de procurar a Deus para responder ao apelo ou ainda capaz de ouvir a Deus de longe.

E como Deus se revela à sua criatura? Segundo Lévinas, a revelação de Deus ao homem se dá sob o modo de mandamento e não sob a forma de conhecimento, Deus não desvela segredos acerca de Sua essência, Deus prescreve Amar. Todos os homens são convocados pela exterioridade deste mandamento e cada singularidade humana só se descobre como tal pela obediência a esta palavra imperativa. Com isto, tanto 0 amor a Deus quanto 0 amor ao próximo não emergem espontaneamente do homem, das decisões autônomas de uma vontade razoável; o amor resulta da feliz intrusão da heteronomia dentro da vida.

Contrariando o pensamento kantiano, Lévinas afirma que 0 amor pode ser mandado e sua essência é ordenar a reciprocidade. Somente 0 amor pode ordenar o amor. A Torá é a inquietação mesma do amor; o mandamento é a presença viva do amor. Com isto, a heteronomia é conduzida pelo amor e guardada por ele e, por isto, o mandamento não contraria a liberdade, mas a convoca para o que de mais alto ela possa pretender e se engajar, a saber, uma humanidade convocada à bondade.

Neste sentido é que se dissipa o aspecto aparentemente contraditório entre liberdade e obediência ou liberdade votada ao próximo. Com efeito, antes de toda escolha livre de uma consciência que se decide eventualmente a operar, agir em favor de outro, antes de toda tomada de posição autônoma, ressoa um apelo que ordena converter sua vida a esta obra, que merece 0 nome de humana. Trata-se, como se vê muitas vezes ao longo de Difícil Liberdade, da anterioridade de um apelo que recebe o nome de eleição: a consciência de uma assignação irrecusável que precede a toda afirmação do Eu, uma anterioridade da responsabilidade sobre a liberdade. Com isto, a moral já não tem seu fundamento na autonomia da razão, mas na orientação para uma Palavra que precede a cada um e Ihe ordena 
o Bem. 0 fundamento ético é an-arquico: "a responsabilidade ilimitada em que me encontro vem de fora de minha liberdade, de algo 'anterior-a-todalembrança', de algo 'ulterior a todo cumprimento', de algo não presente; vem do não-original por excelência, do an-árquico, de algo que está mais aquém ou mais além da essência ${ }^{56}$. Com isto o serviço ao outro como vocação primeira não pode ser relativizado por qualquer desejo de reger, de mandar.

\section{B. Liberdade e Alteridade}

Segundo Lévinas, é um pensamento corrente de que quando um homem assume responsabilidades face ao outro, ele decide com liberdade e conta com a possibilidade de eventuais faltas. Tal posição pressupõe a existência de um sujeito que se engaja e aceita ter de responder, mas não além do campo que excede a sua liberdade. Ora, para Lévinas, uma tal responsabilidade fundada sobre uma escolha livre permanece limitada no espaço e no tempo, ela não conduz para aquilo que ultrapassa esta escolha, ao além do perímetro balizado para o exercício daquela liberdade. A permanência neste pressuposto implicaria em que cada homem se achasse quites, isento de responsabilidade diante do mal - inclusive da morte - que possa acontecer ao outro.

A esta responsabilidade restrita às medidas do engajamento livre de uma consciência, Lévinas opõe, como já indicamos, a realidade de uma responsabilidade infinita. Trata-se de uma responsabilidade pelo mundo que nunca se deixa enquadrar nos limites das decisões livres de uma vontade, pois tal responsabilidade precede à liberdade como responsabilidade do eleito, como "obrigação anacronicamente anterior a todo ato de compromisso" 57, uma responsabilidade "frente aos homens que nem sequer conhecemos" 58 ; numa palavra, responsabilidade por tudo e por todos. 0 eleito é investido por uma espécie de 'carga' que nunca o deixa serenar e repousar, pois é ele que pertence a esta responsabilidade anterior; o eleito não se encontra numa posição de poder decidir a respeito dessa investidura, pois se ele decide e ele decide - suas decisões são posteriores a ela e sempre referidas a ela.

Mesmo não podendo fugir da investidura de eleito e nunca podendo descansar, tal carga não se constitui em algo nefasto ao homem. Ao contrário, esta passividade - no sentido de ter sido eleito - é o fino toque por onde o humano se desvela em suas mais altas exigências. Esta investidura não produz no homem uma espécie de sonolência, inércia ou incapacidade de

\footnotetext{
${ }^{56}$ Cf. AE, 54 e também HH, 102.

${ }^{57} \mathrm{Cf} . \mathrm{AE}, 165$.

58 Ibid.
} 
agir; ela introduz e mantém permanente uma afecção do homem pelo bem e faz do homem um ser vulnerável ao sofrimento alheio de tal maneira que tudo passa a ser de sua conta, mesmo que tenha vontade de se esquivar. Com outras palavras, a eleição ou vocação primeira a servir faz de cada homem o guardião do seu irmão, mesmo se a liberdade - em concreto exercício - se recusar. Nesse sentido, cada homem é como que o refém de seu próximo.

Este é um estatuto 'desconfortável' do sujeito humano, pois o peso do mundo repousa sobre as costas do homem. A questão que se põe é a seguinte: como pensar que eu seja responsável pelo sofrimento dos outros, sofrimento que não foi causado por mim? Ou ainda, não basta que eu responda pelo mal provocado por mim? Para Lévinas, afora estas questões, a responsabilidade não conhece limites. Junto com a noção de criação, esta responsabilidade sem limites é uma das grandes intromissões do mundo judaico no horizonte da Filosofia e efetivamente faz problema para os cânones da filosofia ocidental. A precedência da criação sobre a liberdade e da responsabilidade sobre a justiça razoável produz solavancos no pensamento ocidental. Por uma investidura pre-liminar à liberdade, somos, como diz a Escritura, responsáveis por 'onde está o teu irmão'. Neste prisma, se eu não respondo a não ser de mim, sou ainda Eu?

A questão da resposta ao outro recebe então nova conotação e uma positividade considerável. Com efeito, um primeiro elemento decisivo é que os traços verdadeiramente humanos do Eu estão ligados à responsabilidade pelo outro. Um segundo elemento é que o Eu advém à sua humanidade a cada vez que ele permite que a responsabilidade ultrapasse os limites de sua liberdade. Ligando os dois elementos, temos: eu consinto que a necessidade de estender a mão ao outro tenha precedência e adio para depois a satisfação do meu interesse; é assim que eu venho a ser. De outro modo, eu respondo a uma palavra divina na criação, a um Dizer que ordena a responsabilidade e, por ela, tomo pé no Ser.

O sentido profundo da eleição, inscrita no homem pela criação, consiste em que o Deus de Israel não subtrai os homens de seus deveres, mas os inquieta sempre e os obriga infinitamente. Cada pensamento, cada palavra e cada gesto do homem são penetrados de gravidade. 0 próprio Deus teria necessidade de sua criatura humana para continuar a manter o mundo no Ser, Deus reinaria pela mediação de uma ordem ética, precisamente lá onde um ser responde por um outro. Ora, tal resposta passa pela perda das ilusões da alma, envolta na certeza do seu bom direito de ser, mesmo que isto the provoque entristecimento. A resposta ao outro provoca um despertar que extrai o Eu de suas malhas egoístas que não 0 deixam prestar atenção ao outro.

Pela marca da criação, a alma procura, em si e por si, mais e mais se aproximar de Deus. 0 desejo que a alma tem de Deus não se satisfaz 
assim. Com efeito, quanto mais a alma se esforça por se aproximar Dele, mais ela experimenta a distância que a separa de Deus. Esta inquietude persistente dá o justo sentido da transcendência ou do Infinito: Deus não se deixa enquadrar em nenhuma imagem ou conceito, Ele excede sempre toda medida humana. 0 desejo de Deus é o traço da transcendência no homem, mas também mostra a impossibilidade da criatura de se identificar com o Criador; como tal a criatura permanece separada ${ }^{59}$.

O viver na proximidade de Deus não é possível por uma via solipsista, é um caminho que não se faz sozinho, à deriva do outro. Ao contrário, a proximidade de Deus vai do desejo de Deus convertido em serviço ao próximo. A verdadeira satisfação do amante de Deus se inscreve no desvio infinito na direção do outro e não num êxtase individual. As dores do órfão, da viúva e do estrangeiro, como diz a Escritura, clamam aos céus, impedindo ao homem uma aproximação de Deus pelo silenciamento desses gritos e pelo abafamento de toda a injustiça. Deus tem necessidade dos homens para redimir sua criação.

Estas considerações nos conduzem à relação do Eu com o Outro humano e imprimem um sentido profundo ao aparecer, ao encontrar e ao acolher 0 outro, com conseqüências decisivas para o Eu que se quer humano. Com efeito, o aparecer do outro se dá, segundo Lévinas, como rosto (visage); 0 rosto excede toda a descrição possível e não se deixa encerrar nos moldes do conhecimento; o encontro do outro como rosto faz com que aquele que olha o outro receba dele a revelação de uma verdade que nenhum conhecimento conceptual consegue captar ou transmitir; o encontro com o outro no seu aparecimento a mim me requer imperativamente, permanece separado de mim pela distância invisível da alteridade e exige minha acolhida. Com outras palavras, o encontro do rosto constitui-se numa espécie de choque que nada pode preparar, nem palavras, nem contexto, nem anúncio; 0 rosto simplesmente advém, se manifesta e, como acontecia com Deus a partir da idéia de Deus no Cogito, o outro como rosto, me ultrapassa, não cabe em mim, ele é parte do Infinito. Por isto Lévinas pode dizer que "A idéia do infinito se produz concretamente sob as espécies de uma relação com o Rosto" 60 .

A epifania do rosto mostra-me o outro na sua nudez, na sua vulnerabilidade diante dos meus poderes. Mas, "o rosto se recusa à possessão, aos meus poderes" ${ }^{61}$, mesmo que eu possa ceder à tentação do assassinato. 0 rosto me fala e me convida a uma relação na qual não entre o exercício de alguma forma de poder, nem a luta pelo reconhecimento; também não se trata de uma relação a ser construída sob o finalismo do reconhecimento

\footnotetext{
59 Cf., TI, 41-42.

60 Ibid. 213.

61 Ibid. 215.
} 
mútuo, mas de uma relação onde o outro conta, para mim, mais do que eu mesmo, atualizando a cada encontro o mandamento 'tu não matarás', cuja positividade pode ser dita como 'tu farás tudo para que o outro viva'.

Se o rosto ocupa um lugar privilegiado para Lévinas, é por que ele pensa que Deus vem à idéia, no face-a-face com o outro, que Deus está próximo na proximidade dos outros homens que me interpelam como rosto. 0 Deus que vem à idéia daquele que encontra o outro como rosto não é Ele mesmo redutível à idéia; trata-se do Deus que prescreve e assina todos os mandamentos; e o conteúdo dos mandamentos se endereça à acolhida do outro, ao cuidado infinito do outro que me aparece como rosto e atualiza o mandamento divino. 0 Deus que vem à idéia é Aquele que criou o homem à Sua semelhança e assinala a cada um com seus mandamentos. 0 encontro com o outro reaviva a lembrança de uma anterioridade que precede a mim e ao outro e me abre ao Infinito. A questão do Infinito, de Deus e do outro homem, seria um dos princípios que a filosofia de matriz grega ignorou.

0 aparecimento do outro no encontro me põe logo de saída o imperativo de ter de responder ao apelo de sua presença. Mas a resposta a ser dada não depende de nenhum tipo de movimento do outro em relação a mim ou do eventual cuidado do outro por mim. Ao contrário, segundo Lévinas, o outro me diz respeito mesmo se ele me ignora ou me olha com indiferença, mesmo se se recusa a me reconhecer. A isto Lévinas chama de assimetria ética. A ética me impõe ultrapassar o terreno da luta pelo reconhecimento, da rivalidade e da revanche; numa relação em que um homem dependesse da expectativa ou da reação do outro, não poderia haver propriamente ética, pois essa dependência não levaria, positivamente, a lugar nenhum. 0 imperativo que me antecede me prescreve a responsabilidade sempre primeira pelo outro; com isto, a ética só pode tomar sentido no desinteressamento. A reciprocidade até pode vir a ocorrer, mas ela não pode ser 0 fundamento nem a medida da minha adesão ao outro.

Esta assimetria na relação com o outro pode levar a entender que se trata do desaparecimento do Eu ou de sua anulação pela precedência dada ao outro. Na verdade não é bem assim. Com efeito, Lévinas resolve esta questão, já indicada de passagem anteriormente, propondo uma nova interpretação do versículo bíblico 'tu amarás teu próximo como a ti mesmo' (Lev, 19,18). Para ele, este mandamento não pressupõe que é preciso primeiro amar a si mesmo ou medir o amor concedido ao outro segundo a avareza dos corações cuidadosos de seu próprio bem-estar. Lévinas sugere que se compreenda tal mandamento assim: 'tu amarás teu próximo: isto é a ti mesmo', o que significa, é este amor ao próximo que é tu mesmo. A dimensão propriamente humana do Eu só ganha lugar por e neste amor pelo outro; e este amor não espera gratidão porque ele responde a um imperativo, a uma investidura; ele é que faz surgir a identidade humana 
como identidade ética. Fora disso, cada um se esforçará por ser, não medindo os meios para suprimir os obstáculos que se puserem no percurso; o egoísmo teria suas raízes neste esforço de ser - portanto, no solo ontológico - o que implica na impossibilidade de fundar a ética em bases ontológicas: se cada um levar às últimas conseqüências seu desejo de ser, está instaurado - e justificado - o reino da violência. Por isto Lévinas busca o atrás do Ser, ou o além do Ser, o que nos faz tocar o Infinito: a maravilha do Eu é reivindicado por Deus no rosto do próximo.

As noções de criação e de rosto nos levam a perceber que Deus não equivale ao Ser; Deus é 'anterior' ao Ser, Deus é que fez tudo ser. Antes do Ser há o silêncio, a noite, ao que Lévinas chamou de 'a experiência do il y a'62. Tal experiência permitiria imaginar o vazio absoluto de antes da criação, mas um vazio irredutível ao Nada; o mundo das formas se abre como um abismo sem fundo, nenhuma forma aparece nessa indistinção primitiva do ser, nenhuma existência é reconhecível ou nominável. O livro do Gênesis 1, 2 diz que 'a terra era solidão e caos, as trevas cobriam a face do abismo'. 0 há precede a palavra e a luz, que fazem aparecer as existências singulares e nomeáveis. E foi somente depois da obra de distinção que Deus declarou que Sua criação era boa. Como obra da criação de Deus, que fez tudo ser, o homem está, por assim dizer, 'condenado a ser', está impossibilitado de fugir do ser. Mas a realização do homem, passará pela realização da investidura que, junto com o desejo ou 'necessidade' de ser, já vem inscrita na criação, sob a forma do Mandamento, que é como que a orientação para que o homem possa sair da solidão e dureza de ser, fazendo de cada homem o guardião do seu irmão. 0 humano se anuncia no Ser quando o Eu depõe a sua soberania de Eu e prefere sofrer a injustiça a cometêla atendendo a uma convocação silenciosa advinda da fraqueza dos homens; o Eu é uma resposta a um apelo que o precede, mas tal é também a sua unicidade.

Pela criação, pois, Deus deixa lugar a um ser separado, o homem, mas mantém relação com ele; pela criação se produz no homem a idéia do Infinito: Deus criou o homem, mas pôs no homem apenas a Sua idéia e não Se pôs totalmente nele. Pela criação o homem é capaz de entrar em relação com Deus, que transcende o mundo, os outros homens, numa palavra, transcende o Ser; pela criação o homem 'é capaz de receber uma revelação'63; a forma concreta de receber a revelação é a responsabilidade ética até redimir aquele cujas necessidades me foram reveladas. É assim que "a dimensão do divino se abre a partir do rosto humano"64 e convoca, desde

62 LÉVINAS, E., Da Existência ao Existente. Campinas (SP): Papirus, 1998. Ver especialmente da página 67 a 75 .

${ }^{63} \mathrm{Cf} ., \mathrm{TI}, 88$.

64 Ibid. 76. 
sempre, o homem a realizar sua vocação de Santidade, ao ponto de substituir e expiar o outro.

\section{Apontamentos Condusivos}

Depois de termos percorrido dois caminhos na questão do fundamento da Ética, o caminho kantiano e o caminho lévinasiano, tecemos agora algumas breves aproximações e indicamos algumas das principais diferenças entre eles, à guisa de conclusão. Para tanto, retomaremos algumas das teses fundamentais de Kant e Lévinas.

Uma primeira aproximação é que a busca de uma fundamentação radical para a moralidade é o decisivo nos dois caminhos. Com efeito, tanto Kant quanto Lévinas são dois marcos pelos quais necessariamente hão de passar todos aqueles que ousam, num tempo eticamente cético ou moralmente relativista, pensar ou retomar o pensamento sobre a questão do homem, do valor, do fim do homem, da realização humana e - por que não! - da virtude. Temos em Kant a radicalidade do 'deves porque deves' e, em Lévinas, 'o responder ao outro ao ponto de tirar o pão da própria boca'.

A radicalidade indicada, por sua vez, segue em ambos um movimento que poderíamos chamar de abertura da subjetividade humana, mesmo que o percurso de cada movimento contenha diferenças importantes por relação ao outro. No caso de Kant, podemos dizer que ele 'abre' o Homem e afirma a possibilidade do Conhecimento, ao descobrir no próprio Sujeito as condições universais da possibilidade do mesmo, tendo como referência de conhecimento verdadeiro a ciência da natureza. A conclusão desta primeira abertura é de que o conhecimento é possível, mas restrito ao âmbito fenomênico, ficando barrado o caminho cognoscitivo da Razão no reino da coisa-em-si; a razão cognoscitiva como que ante-vê o mundo noumênico, é habitada por idéias que possuem um uso regulativo na organização dos fenômenos, mas não pode avançar cognoscitivamente nesse 'mar aberto', porque faltariam ao sujeito as condições para tal.

Reabrindo o Sujeito e abrindo de novo a Razão, Kant descobre outra função da mesma razão: além do uso teórico, há um uso prático. Abrindo, por sua vez a razão enquanto capaz de agir, descobre a vontade; abrindo agora a vontade, Kant percebe que ela pode ser determinada tanto por aquilo que é empiricamente condicionado quanto por aquilo que é puro, que não depende de condições empíricas. Percebe também que o homem, além de princípios morais válidos subjetivamente, é também capaz de formular princípios universais, categóricos, cuja validade se estende a todo ente racional. Kant descobre então a lei moral, como princípio universal ou, o que é o mesmo, como imperativo categórico, ao qual se devem adequar 
todas as máximas subjetivas. Abrindo a lei moral, Kant descobre a liberdade como condicão de possibilidade da lei moral; e abrindo a liberdade descobre-a como autonomia, como o incondicionado de toda a ação que se quer moral.

No âmbito da liberdade Kant descortina a exigência do sumo bem, compreendido por ele como virtude e felicidade, com precedência da primeira sobre a segunda. Neste movimento, percebe que a realização do sumo bem, mesmo sendo uma exigência da razão pura prática, não é algo possível neste mundo; isto o levará a postular, além da Liberdade, a imortalidade da Alma e a Existência de Deus. Com outras palavras, é numa outra vida que é possível a realização do sumo bem.

Vejamos agora o movimento de abertura em Lévinas. Com efeito, seguindo a esteira cartesiana e kantiana, Lévinas 'abre' a Subjetividade humana e descobre nela a idéia do Infinito; em vez de seguir a rota cartesiana que busca garantias e novos conteúdos para o Cogito, Lévinas, por assim dizer, vai atrás do Infinito e o descobre como o Outro do Cogito, como Deus transcendente, Aquele cuja realidade não cabe no Cogito que Dele possui a Idéia. Abrindo agora a alteridade, descobre que o outro humano também transcende o Eu cognoscente; abrindo o outro, descobre- o como rosto, cuja verdade ultrapassa toda intencionalidade objetivante. Abrindo o rosto do outro, Lévinas afirma que é pelo outro que Deus vem à idéia, o rosto do outro é epifania, é revelação do Infinito ao homem.

É então que no percurso de Lévinas entra a proposta ou os conteúdos da Escritura judáica e da tradição talmúdica. De fato, Lévinas introduz a noção de Criação e de Deus Criador como conceitos e realidades a serem pensadas filosoficamente, ligando-as à questão do Infinito. A noção de criação será determinante pois será a partir dela que todo o humano será compreendido e interpretado e nele a Ética: antes da constituição da Subjetividade a partir de si e por si mesma, há uma anterioridade criatural que investe e determina a presença do homem no mundo, investindo e votando cada liberdade ao cuidado do outro, sob a forma do Mandamento. É então que o fundamento ético pertence ao reino da heteronomia. Com isso, o movimento lévinasiano é parecido com o de Kant, mas o resultado é profundamente diferente.

Outra aproximação entre Kant e Lévinas é a que diz respeito ao 'lugar' do amor-próprio e do egoísmo. Com efeito, em Kant o amor-próprio está do lado do empiricamente condicionado e, portanto, do lado do desejo de felicidade, sendo incapaz de fundar a moralidade. No máximo, o amorpróprio serve de fundamento para as máximas que sempre permanecem subjetivas e, como tal, com uma validade particular. Em Lévinas, por sua vez, o egoísmo procede da tendência dada ao homem, junto com a investidura da liberdade na criação, de tentar ser; o esforço por ser pode levar o homem, quando não orientado pela Palavra, a não medir os meios 
para conseguir seus propósitos. A guerra e toda violência teriam sua origem nesse connatus, nesse esforço por ser.

Aprofundando esta aproximação, podemos dizer que tanto em Kant quanto em Lévinas há um pano de fundo que joga um papel decisivo. Com efeito, em ambos a questão da ação tem proeminência sobre a questão do conhecimento - a razão prática pura em Kant e o cuidado do outro em Lévinas - sobretudo no que se refere ao conhecimento científico. No caso de Kant a dimensão da coisa-em-si, que, mesmo pela via prática, não é cognoscível, mas postulável como exigência da mesma razão, joga um papel decisivo na realização do sumo bem. Em Lévinas temos a possibilidade de penetração nessa esfera noumenal, cujo conteúdo e forma de tematização são oriundos da tradição judáica. Se em Kant, porém, Deus permanece um postulado prático, em Lévinas vamos encontrar a possibilidade, para 0 homem, de viver na presença de Deus. Para Kant a santidade pertence a uma vontade santa; em Lévinas todo homem é convocado à santidade.

Mas se para Kant todo o processo e progresso da moralidade está totalmente centralizado no Sujeito que se descobre como Liberdade e se afirma como Autonomia, em Lévinas uma tal liberdade não é capaz de justificar a si mesma e, como tal, não pode ser o último fundamento da moral. Talvez aqui, mesmo que haja uma proximidade temática, seja o 'lugar'da maior distância entre ambos. Lévinas vai buscar a 'situação' anterior ao exercício da liberdade e é 'ali' que ele descobre a 'criaturalidade', que vai determinar o exercício de todas as faculdades do homem. Neste sentido, ultrapassando Kant que abriu e fechou a porta do noumenon e contra Heidegger que pôs o homem como pastor do Ser, Lévinas afirma uma 'anterioridade ao ser', o Há que antecede a própria Criação, na qual todo ente vem a ser. É o primado da Heteronomia. O desejo de ser procede dessa criaturalidade e junto dele o homem recebe uma investidura que orienta seu conhecimento e sua liberdade para a responsabilidade sempre incompleta diante do outro. 0 desejo de ser, inextirpável porque é dado com a criação mas também capaz de levar à violência, e a investidura na direção do outro só podem ser resolvidos pela primazia da investidura sobre aquele desejo.

E mais uma vez encontramos a proximidade. Com efeito, em Kant, como já indicamos, a solução do conflito entre desejo de felicidade e virtude só era possível pela pressuposição de uma causa anterior a ambos, mas ao mesmo tempo diferente de cada uma, a partir da qual seria possível pensar uma teleologia na qual felicidade e virtude por fim viessem a confluir. Tal processo seria consumado em última instância pelo próprio Deus. Em Lévinas temos a afirmação dessa Causa como sendo o Deus Criador: ao criar o homem como desejoso de ser e investido por uma responsabilidade que é anterior ao exercício da liberdade, Deus, pela sua Palavra, pela Revelação permanente no Rosto do outro, é em última instância quem garan- 
te, para o homem que se decide a responder, a realização da vocação da santidade.

Por fim, podemos dizer: a lei moral da liberdade faz um percurso autônomo e chega a Deus; em Lévinas, o $M$ andamento prescreve o cuidado do outro para cada liberdade deslocando a centralidade da determinação para a Alteridade, para a Heteronomia. Mas nos dois casos, a identidade do Eu (soi) se mede pelo índice moral vivido: em Kant, o grau de virtude; em Lévinas, o grau do cuidado do outro. Com outras palavras, Kant é fiel à sua Revolução Copernicana, em que tudo gira ao redor do Sujeito; Lévinas faz uma espécie de Segunda Revolução Copernicana ao fazer tudo girar ao redor do Outro, numa espécie de 'Ética como Filosofia Primeira'. As Proximidades são muitas e as diferenças às vezes sutis, como o caso dos próprios nomes: Immanuel Kant (com 'I') e Emmanuel Lévinas (com 'E').

Endereç do Autor:

Rua Raimundo Vieira do Espírito Santos, 39

Ed. Flávia II - Apto. 202

29042-752 Vitória - ES

e-mail: gfbonamigo@yahoo.com.br 